\title{
Fars edebiyatındaki ilk mersiyeler
}

\section{Çetin KASKA'}

\begin{abstract}
APA: Kaska, Ç. (2019). Fars edebiyatındaki ilk mersiyeler. RumeliDE Dil ve Edebiyat Araştırmaları
\end{abstract} Dergisi, (15), 253-262. DOI: 10.29000/rumelide.580566

\section{$\ddot{\mathbf{O} z}$}

Mersiye ölen birinin ardından duyulan üzüntüyü dile getirmek ve o kişinin iyi taraflarını anlatmaktır. Fars edebiyatında müstakil mersiyesi günümüze ulaşan ilk şair Rûdekî'dir. Rûdekî'den hemen sonra Ebû'l-Abbâs Fazl b. Abbâs Rebincenî ve Ebû Mansûr Ammâre-i Mervezî gibi şairler mersiye yazmışlardır. Fars edebiyatında yazılan mersiyeler konularına göre resmî, şahsi, dinî, tasavvufî ve felsefî olarak ayrılmaktadır. Fars edebiyatının en iyi şairleri olan Firdevsî, Hâkânî-i Şirvânî, Sa'dî, Hâfız ve Abdurrahmân-i Câmî gibi şahıslar da mersiye yazmışlardır. Mersiyeler kaside, mesnevi, gazel ve rubai gibi nazım şekilleriyle yazılmıştır. Farsça yazılan mersiyelerde dünyanın vefasızlı̆̆ı, zamanın geçici oluşu ve feleğe sitem gibi konular ele alınmıştır. Fars edebiyatında mersiyeleri günümüze ulaşan ilk üstatlar Sâmânî dönemi şairleridir. Bu makalede Fars edebiyatında mersiyenin nasıl işlendiği açıklanmış ve ilk yazılan mersiyeler ele alınıp tercümeleri yapılmıştır.

Anahtar kelimeler: Mersiye, Rûdekî, Fars edebiyatı, Fars şairleri.

\section{The first mersiyes (elegies) in the Persian literature}

\begin{abstract}
"Mersiye" (elegy) is the form of poetry that is used to express the sorrow for and the good features of a dying person. The first poet whose independent elegy reached our day is Rûdekî. After him the poets like Ebû'l-Abbâs Fazl bin Abbâs Rebincenî and Ebû Mansûr Ammâre-i Mervezî wrote elegies. The elegies written in the Persian literature are classified into official, personal, religious, sophistic and philosophical elegies according to their subjects. The best poets of the Persian literature like Firdevsî, Hâkânî-i Şirvânî, Sa'dî, Hâfiz and Abdurrhmân-i Câmî wrote elegies. The first masters of the Persian literature whose elegies reached our day are the poets of the Samanid period. In this article we explain how elegies are handled in the Persian literature, we deal with the first elegies, and make their translations.
\end{abstract}

Keywords: Elegy, Rûdekî, Persian literature, Persian poets.

\section{Giriş}

Mersiye kelimesinin lügat manası "ölen birinin ardından iyiliklerini sayarak acıyı ağlamaktır” Fars, Türk ve Arap edebiyatlarında ölenin ardından duyulan üzüntüyü dile getirmek ve o kişinin iyi taraflarını anlatmak için yazılan lirik şiirlere mersiye denilmiştir. İslam öncesi Fars edebiyatında yazllan mersiyeler hakkında detaylı bilgiler yoktur. Ancak mersiyenin o dönemde yazıldığına dair belirtiler bulunmaktadır. Merzkû adlı bir dinî önder adına Eşkânî Pehlevice yazılan Risâle-i Merzkû günümüze ulaşmıştır. İslâmî dönem Fars edebiyatında yazılan en eski mersiye Ebû'l-Yenbagî Abbas b.Tarhân’ın Derî Farsçası ile

1 Arş. Gör. Dr., İstanbul Üniversitesi, Edebiyat Fakültesi, Fars Dili ve Edebiyatı Bölümü, (İstanbul, Türkiye), cetinkaska@hotmail.com, ORCID ID: 000o-0002-1168-5522 [Makale kayit tarihi: 21.05.2019-kabul tarihi:20.06.2019; DOI: $10.29000 /$ rumelide.580566] 
yazdığı altı kıtalık "Semerkant'ın harabe haline gelmesi” adlı mersiyesidir. Bu mersiye İbn Hurdâzbih’in el-Mesâlik ve'l-memâlik adlı eserinde bulunmaktadır. Ayrıca Muhammed b. Vasîf Sistânînnin Târîh-i Sîstân adlı eserindeki kaside şeklindeki on bir beyitlik mersiyesi Fars edebiyatında yazılan eski mersiyelerdendir. (Türk Dili ve Ansiklopedisi, 1986:272; Yazıcı, 2004:217; Provençal, 1987:772-73; Dihhudâ, 1377:20617)

Fars edebiyatında müstakil mersiyesi günümüze ulaşan ilk şair Rûdekî'dir. Rûdekî kendi muasırları olan Ebû'l-Hasan Murâdî ve Şehîd-i Belhî gibi şairlerle Sâmânî emiri Ahmed b. İsmâîl veya İsmail b. Ahmed için mersiyeler yazmıştır. Rûdekî'den sonra şair Ebû'l-Abbâs Fazl b. Abbâs Rebincenî h. 331 yıllında Nasr b. Ahmed Sâmânînin ölümü için bir mersiye kaleme almıştır. Rebincenî bu mersiyesinde Nûh b. Nasr'ın tahta çııışını da tebrik etmiştir. Rebincenî'den sonra Sâmânî döneminin son şairi Ebû Mansûr Ammâre-i Mervezî, Ebû İbrâhîm İsmâîl b. Nûh'un h. 395 yllında öldürülmesi üzerine bir mersiye yazmıştır. (Selçuk, 2013:7-9)

\section{Fars edebiyatında mersiye}

Mersiyeler konularına göre resmî, şahsî-ailevî, dinî ve felsefî olarak ayırılmaktadır. Resmî mersiyeler padişahlar, vezirler, ülke büyükleri veya onlara yakın olan kimseler hakkında yazılmıştır. Bu tür mersiyeleri genellikle saray şairleri kaleme almıştır. Saray şairleri bu mersiyeleri ya emirle veya aldıkları caize sebebiyle kaleme almışlardır. Bu mersiyeler resmî oldukları için kuru, ruhsuz ve fazla mübalağalıdır. Ferruhî-i Sîstânînnin h.421 yıllında vefat eden Gazneli Mahmud için yazdığı mersiye, Am'ak-i Buhârî’nin Sultan Sencer'in emriyle kızı Mah Melek Hâtun için yazdığı mersiye, Emîr Muizzînnin Selçuklu Sultanı Melikşâh için yazdığı mersiye, Enverî̀nin dönemin büyüklerinden olan Seyyidü'l-Sâdât Mecdüddîn Ebî Tâlib b. Ni'me için söylediği mersiye, Hâkânînnin İmam Muhammed Yahyâ hakkında söylediği mersiye ve Sa‘dî’nin Salgurlu Sa‘d b. Ebûbekr ve Ebûbekr Sa‘d b. Zengî gibi kişiler için yazdığı mersiyeler saray şairleri tarafından görev gereği saray ehli hakkında yazılan resmî mersiyelere örnektir. Fars şiirinin başlangıcından hicri sekizinci yüzyılla kadar kaside nazım şekliyle daha çok resmî mersiyeler yazılmıştır. Ancak Safevî hükümeti döneminde dinî mersiye revaç kazanmış ve mersiyeler daha çok terkibibend nazım şekliyle kaleme alınmıştır. (Asîl, 1381:1242-43; Yazıcı, 2004:217-18; Fesâ̂̂, 1373:209-10)

Taziye ile beraber onun yerine geçeni de tebrik eden mersiye türünün ilk örneğini Ebû'l-Abbas Fazl b. Abbâs-i Rebencenî kaleme almıştır. Rebencenî bu mersiyesinde Sâmânî hükümdarı Nasr b. Ahmed’in ölümü üzerine taziye yazmış ve onun yerine geçen Nûh b. Nasr'ı tebrik etmiştir. Ferruhî’nin Gazneli Mahmud'un ölümü ve oğlu Muhammed'in tahta geçmesi için yazdı̆̆ı mersiye ile Emîr Muizzînin Fahru'l-Mülk'e ağıt ve oğlu Kavvâmu'l-Mülk'ü tebrik için yazdığı mersiye bu türdendir. Son dönem şairlerinden Fethalîhân Sabâ, Âkâ Muhammed Hân Kâcâr'ın ölümü ve Fethâlî Şâh'ın tahta geçmesi hakkında bu tarz bir mersiye yazmıştır. Yine Cemâleddîn-i İsfahânî’nin Hanefi mezhebinin ileri gelen âlimlerinden olan Rükneddîn-i Saîd’i tebrik ve kardeşi Kavvâmuddîn-i Saîd'e ağıt şeklindeki mersiyesi bu türdendir. Şairler mersiyeleri terciibend, kıta, terkibibend, kaside, mesnevi, gazel, ve rubai gibi nazım şekilleriyle yazmışlardır. Örneğin Firdevsî mersiyelerini Şâhnâme'de mesnevi, Hâfız ve Hümâm-i Tebrîzî mersiyelerini gazel ve Hâkânî mersiyelerini kaside, kıta ve rubai nazım şekilleriyle yazmıştır. Ancak mersiyede en çok tercih edilen nazım şekli kasidedir. Mersiyeler muzari, hezec, remel, müctes, hafif, müsterih, serî, ve karîb gibi bahirlerle söylenmiştir. (Secâdî, 1373:10; Asîl, 1381:1242-43; Yazıcı, 2004:217-18; Selçuk, 2013:11-12, 20) 
Fars edebiyatında bir diğer mersiye türü şahsî mersiyelerdir. Bu mersiyeleri şair kaybettiği akrabaları, annesi, babası, kardeşleri, arkadaşları ve maşuku sebebiyle kaleme almıştır. Bu tür mersiyeler duygusal, kederli ve anlam yüklüdür. Firdevsî’nin h.394 yıllında 37 yaşında vefat eden oğlu için yazdığı mersiye bu türe ilk örnektir. Hâkânî-i Şirvânînnin h.570 yıllında henüz yirmi yaşındayken vefat eden oğlu Emîr Reşîüüdîn ve kendisini himaye edip, Arapça öğreten ve Hassânü’l-Acem unvanı veren amcası Kâfiyüddin Ömer b. Osman'ın h.545 yıllında ölümü nedeniyle yazdı̆̆ı mersiyeler, Mes'ûd-i Sa'd-i Selmân'ın şair Seyyid Hasan-i Gaznevî ve vefat eden oğlu Sâlih için yazdığı mersiyeler, Senâînin şair Emîr Muizzî için söylediği mersiye, Nizâmî-i Gencevînnin vefat eden şair Hâkânî-i Şirvânî için yazdığı bir beyitlik mersiye, Kemâleddîn-i İsfahânînnin oğlu ve babasının ölümü üzerine yazdığı mersiyeler, Nâsır-i Hüsrev'in Leylâ ve Mecnûn'da kardeşi ve annesinin ölümü üzerine söylediği mersiye, Muhteşemi Kâşânînnin kardeşi, Abdurrahman-i Câmî’nin oğlu ve kardeşi, Feyzî-i Dekkenî’nin oğlu, Rûdekî’nin Şehîd-i Belhî ve Ebû'l-Hasan Murâdî, Lebîbî-i Horasânî’nin Ferruhî-i Sîstânî, Bahâr'in Cemîl Sadîkî, Işkî, Pervîn Ítisâmî ve İrec Mirzâ için yazdığı mersiyeler, Hâfız ve Sa'dî’nin oğulları ve muasır şairler Irâkî, Ahmed Şâmlû, Mehdî Ehvânsâlîs ve Sohrâb-i Sipihrînnin Fürûg-i Ferruhzâd için yazdığı mersiyeler şahsî mersiyelere örnektir. (Kâzî, 1373; Asîl, 1381:1242-43; Yazıcı, 2004:217-18; Selçuk, 2013:12-15)

Hâkânî şahsî mersiyelerin yanında mezhebî, felsefî ve saray ile ilgili mersiyeler de yazmıştır. Hâkânî’nin yirmi bir mersiyesi kaside, on dokuzu kıta ve dördü terkibibendi nazım şekliyle söylenmiştir. İşiteni en çok etkileyen mersiye türü dinî mersiyelerdir. (Şânzerî, 1394:139-156)

Şahsî mersiyenin bir türü de şairin hikâyelerindeki kahramanlar hakkında mersiyeler yazmasıdır. Bazen şair kahramanlarıyla bir olup aradaki mesafeyi kaldırır. Şair kahramanın başına gelenleri kendi başına gelmiş gibi görür. Kahramanın ölmesi şairin üzülüp kederlenmesine neden olur. Bu keder nedeniyle şair mersiyeler yazar. Örneğin Firdevsî, Şâhnâme'deki kahramanlar olan Sohrâb, Siyâveş, İsfendiyâr ve Rüstem için bu tür mersiyeler yazmıştır. Ayrıca buna benzer mersiyeler Nizâmî’nin Hüsrev-i Şîrîn ve Gürgânî’nin Vîs ü Râmîn adlı eserlerinde bulunmaktadır. Şahsî mersiyenin bir türü de şairin daha hayatayken ölüm ve hayat, ölümün yaklaşması, ahiret hayatı için azık toplamadan ömrün heba olması ve hakiki maşuka kavuşmak gibi konuları elle aldığı mersiyelerdir. Bu tür mersiyelerin en güzel örneğini Pervîn İt'isâmî mezar taşı için yazmıştır. Ayrıca bu konuda Îrec Mîrzâ da güzel bir şiir kaleme almıştır. Fars edebiyatı tarihinde her bir şair kendi özel düşünce ve fikri çerçevesinde mersiye yazmıştır. Mersiyelerin dili sade ve basittir. Hatta muğlak yazan şairler bile mersiyelerde sade bir dil tercih etmişlerdir. (Muhammedî, 1387:61-63; Asîl, 1381:1242-43; Yazıcı, 2004:217-18)

Üçüncü mersiye türü dinî mersiyelerdir. Bu tür mersiyeler Kerbelâ hadisesi, dinî önderler, din âlimleri, imamların öldürülmesi ve Hz. Hüseyin'in şehadetiyle ilgili yazılan mersiyelerdir. Bu tür mersiyeler özellikle İran'da Şia mezhebinin yayılmasıyla Fars edebiyatında geniş ölçüde ele alınmıştır. Bu türün ilk örneklerinden birisi hicri altıncı yüz yıllın ilk yarısında şair Kavâmî-i Râzî tarafından yazılmıştır. Mirza Abdülcelîl, Hâcû-yı Kirmânî ve Selmân-i Sâvecî gibi şairler Hz. Hüseyin'in şehadetini dille getirmişlerdir. Kerbelâ'daki Şîa imamlarının şehadeti hakkında ilk kitap yazan kişi Mollâ Hüseyin Vâizi Kâşifı'dir. Kitabın adı Ravzatü'l-Şühedâ'dır. Safevîler'den itibaren şairlerin birçoğu dinî mersiye yazmıştır. Hicri dokuzuncu yüzyılda Kerbelâ hadisesi ve imam menkıbeleri hakkında şiir yazan şairler şunlardır: Kemâl Giyâseddîn-i Şînâzî, Bâbâ Sevdâî-i Ebîverdî, Tâceddîn Hasan Tûnî-i Sebzevârî, İbn Hüsâm-i Kehistânî, Hâce Evhad-i Sebzevârî, Lütfullâh-i Nîşâbûrî ve Kâtibî-i Terşîzî. En meşhur dinî mersiye Safevî hümdarı I. Tahmâsb devrinde on iki bent halinde Muhteşem-i Kâşânînnin Hz. Hüseyin ve arkadaşları hakkında yazdığı terkibibenddir. Bu meşhur mersiye birçok şair tarafından taklit edilmiştir. Hicri on üçüncü yüzyll başları şairi Hâc Süleymân Sabâhî Bîdglî-i Kâşânî, Hz. Hüseyin ve arkadaşları için Muhteşem’i örnek alıp bir terkibibend yazmıştır. Mîrzâ Kûçek lakaplı Mîrzâ Muhammed 
Şefi‘ ve Visâl-i Şîrâzî, Hz. Hasan için birer terkibibend yazmışlardır. Surûş-i İsfahânî, Muhtşem’i taklit ederek 60 bentten oluşan bir terkibibend kaleme almış ve dinî şiirlerini Şemsü’l-Menâkıb adındaki bir mecmuada toplamıştır. Mîrzâ Mahmûd Hân Meliku'ş-şuarâ, Hz. Hüseyin hakkında fasih, kederli ve on dört bentten oluşan bir terkibibend yazmıştır. Mîrzâ Nûrullâh İmân-i Sâsânî, Mîrzâ Muhammed Takî Neyyir, Hüseyin Pejmân Bahtiyârî, Melikü'ş-şuarâ Bahâr, Emîrî Fîrûz-i Kûhî, Muhammed Hüseyin Şehriyâr, İkbâl-i Lâhorî, Celâleddîn Humâî, Alî İnsânî ve Müşfik-i Kâşânî gibi şairler de üçüncü imam hakkında dinî mersiyeler yazmışlardır. (Selçuk, 2013:15-19; Asîl, 1381:1242-43; Yazıcı, 2004:217-18)

Sel, veba ve deprem gibi afetlerle toplu katliamlar dolayısıyla mersiyeler yazılmıştır. Kemâleddîn-i İsfahânî’nin Moğollar'ı İsfahân halkını kılıçtan geçirmesini anlatan şiiri ve Sa 'dî-i Şîrâzî’nin Moğol istilası nedeniyle Bağdat'ın düşüşü ve Abbâsî halifesinin öldürülmesi üzerine yazdığı şiirler, Katrân-i Tebrîzînnin Tebrîz'de meydana gelen depremi anlattı̆̆ı şiiri, Evhadüddîn-i Enverî̀nin Horasan depremini anlatığı şiiri, Hâkânî-i Şirvânî̀nin h.569 yıllında kaleme aldığı Medâin şehrinin harap olması şiiri, Selmân-i Sâvecî’nin Azerbaycan ve Kuzey İran şehirlerindeki kıtlığı anlattığı kıtaları bu tür mersiyelere örnektir. (Asîl, 1381:1242-43; Yazıcı, 2004:217-18)

Ferruhî-i Sîstânî’nin mersiyesinden birkaç beyit:

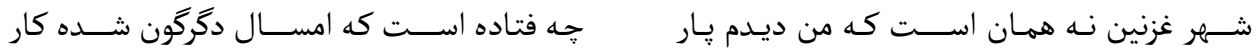

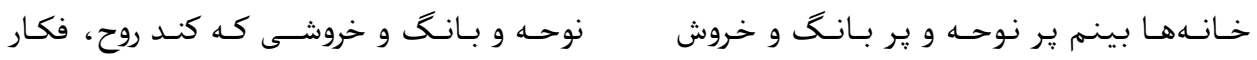

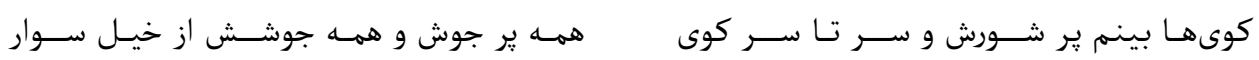

Gazne şehri geçen yll gördüğüm gibi değil. Bu yll ne oldu da bu kadar değişti.

Evleri ağıt, feryat ve çığlık dolu görüyorum. Bu ağıt, feryat ve çığllk ruhu düşünmeye sevk ediyor.

Sokakları ızdırapla dolu görüyorum. Sokaklar baştanbaşa çığlık dolu, bütün çı̆̆lık ve bütün feryat yılkı atındandır. (Ferruhî-i Sîstânî, 1335:90,92)

Firdevsî-i Tûsî̀nin mersiyesinden birkaç beyit:
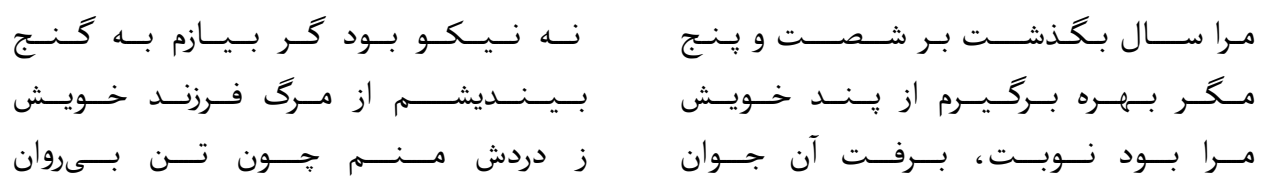

Artık yaşım altmış beşi geçti. Hazine (Şâhnâme) ile nazlanmam iyi değildir.

Eğer öğüdümden nasipleneceksem, oğlumun ölümünü düşünmeliyim.

Sura bendeydi ama o genç gitti. Derdinden ruhsuz ten gibiyim. (Firdevsî, 387)

Hâfız-i Şîâ̂zînin mersiyesinden birkaç beyit:
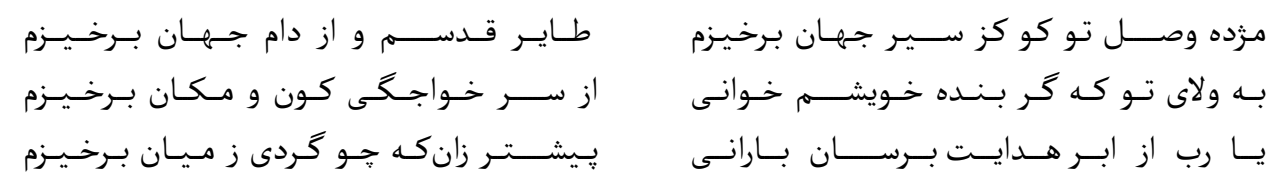

Vuslat müjden nerede, cihandan vazgeçeyim. Kutsi kuşum, dünya damından kalkayım.

Beni kulun olarak kabul edersen dostluğuna ant olsun, bütün varlı̆̆ın efendiliğinden vazgeçerim.

Ya rab! Ben toz gibi ortadan kalkmadan önce hidayet bulutundan bir yağmur yağdır. (Hâfız, 1341:142)

Sa dî-i Şîrâzî’nin mersiyesinden birkaç beyit: 

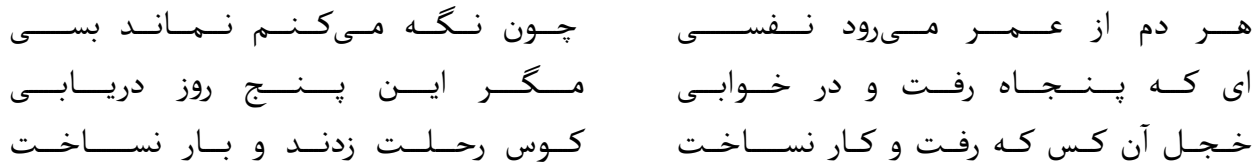

Her dem ömürden bir nefes tükeniyor. Bakınca çok kalmadığını görüyorum.

Ey elliyi devirip hala uykuda olan kişi, sanki bir daha bu elli günü bulabilecek misin?

Gidip bir iş yapmayan kimseye yazıklar olsun, göç davulunu çaldılar ama henüz yükünü hazırlamadı.

(Vezînpûr, 1374:24)

Muhteşem-i Kâşânî’nin mersiyesinden birkaç beyit:
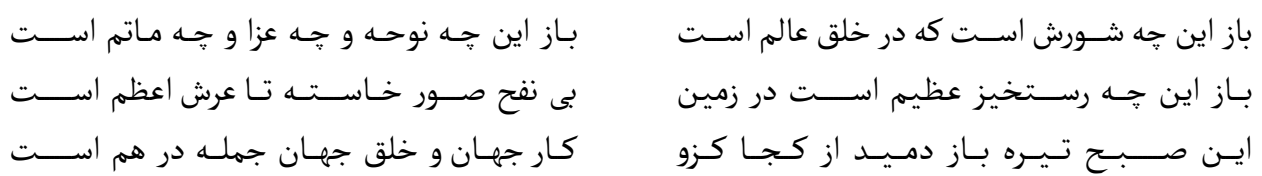

Yine âlem halkından yükselen bu feryat nedir? Yine bu ağıt, bu yas, bu matem nedir?

Yine yerdeki bu azim mahșer nedir. Sura üflenmeden arşa kadar kalkmıș.

Yine bu karanlık sabah nereden doğdu. Ondan dünya işleri ve dünyadaki insanların hepsi perişandır. (Muhteşem-i Kâşânî, 1348:280)

Fürû̆ğ Ferruhzâd’ın mersiyesinden birkaç beyit:
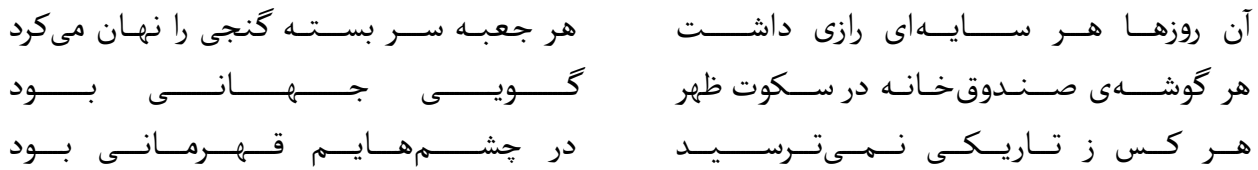

O günlerde her bir gölgenin bir sırrı vardı. Her kapalı kutu bir hazine saklıyordu.

Sandık odasının her bir köşesi zahiri sükûtaydı. Sanki evrenseldi.

Herkes karanlıktan korkmuyordu. Gözlerimde bir kahraman vardı. (Şemîsâ, 1385:367)

Mevlânâ’nın mersiyesinden birkaç beyit:
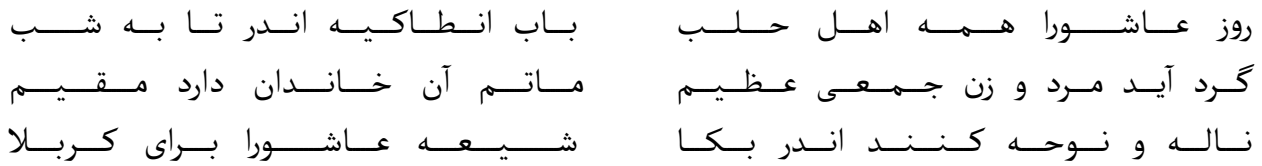

Aşure günü geceye kadar bütün Halepliler Antakya kapısına gelirlerdi.

Kadın, erkek büyük bir kalabalık toplanır, ehli beytin yasını tutarlardı.

Bağırıp feryat ederlerdi, Şîa ve Kerbela vakası için yas tutarlardı.

Fars Edebiyatında ilk mersiye yazanlar Sâmânî dönemi şairleri olan Rûdekî, Rebîncenî ve 'Ammâre-i Mervezî̀dir.

Rûdekî: Acem şâirlerin öncüsü, şâirlerin sultanı ve Fars şiirinin babası gibi adlarla anılmıştır. Semerkant'ın Rûdek kasabasının Bennüc kariyesinde dünyaya gelmiştir. Hicri üçüncü yüzyılın ortalarında doğduğu tahmin edilmektedir. Mahlası için iki rivayet mevcuttur. Bir rivayete göre Rûd adındaki müzik aletini çaldığı için, diğer rivayet ise Semerkant'ın Rûdek kasabasında doğmasından dolayı Rûdekî olarak anılmıştır. Sâmânî Emîri Nasr b. Ahmed’in ilgisini çeken Rûdekî, onun sarayında 
yer bulup, çeşitli ödül ve bağışlar sayesinde büyük bir servette sahip olmuş ve saraydaki şairler tarafindan kıskanılan üstün bir makam elde etmiştir. Avfî ve Mollâ Câmî̀ye göre Rûdekî doğuştan kör doğmuş ancak Rûdekî hakkında bilgi veren Sem‘ânî, Nizâmî-i Arûzî ve Târîh-i Sîstân yazarı onun kör olduğu ile ilgili bir şey söylememişlerdir. Sâmânî devletinin başkenti Buhara'da görkemli bir hayat süren Rûdekî ömrünün son dönemlerinde çok büyük sıkıntılar çekmiş ve fakir düşmüştür. Moğol saldırıları ve çeşitli nedenlerden dolayı Rûdekî̀nin şiirlerinden sadece 1047 beyit günümüze ulaşmıştır. Unsurî, Firdevsî, Mollâ Câmî, Nasır-i Hüsrev, Nizâmî-i Arûzî, Kısâî-yi Mervezî, Mu'ammerî-i Gorgânî gibi şairler Rûdekîye övgüde bulunmuşlardır. (Nefîsî, 1336: 14-411; Öztürk, 2008:185-186; Şâfiî, 1380: 25-31; Hânlerî, 1347: 238; Devletşâh, 1337:36-39; Hidâyet, 1339:681-688; Avfî, 1361: 6-8; Safâ, 1338:371-389)

Rûdekî, Sâmânî emiri İsmail b. Ahmed veya Ahmed b. İsmâîl'in ölümü nedeniyle bir mersiye yazmıştır:
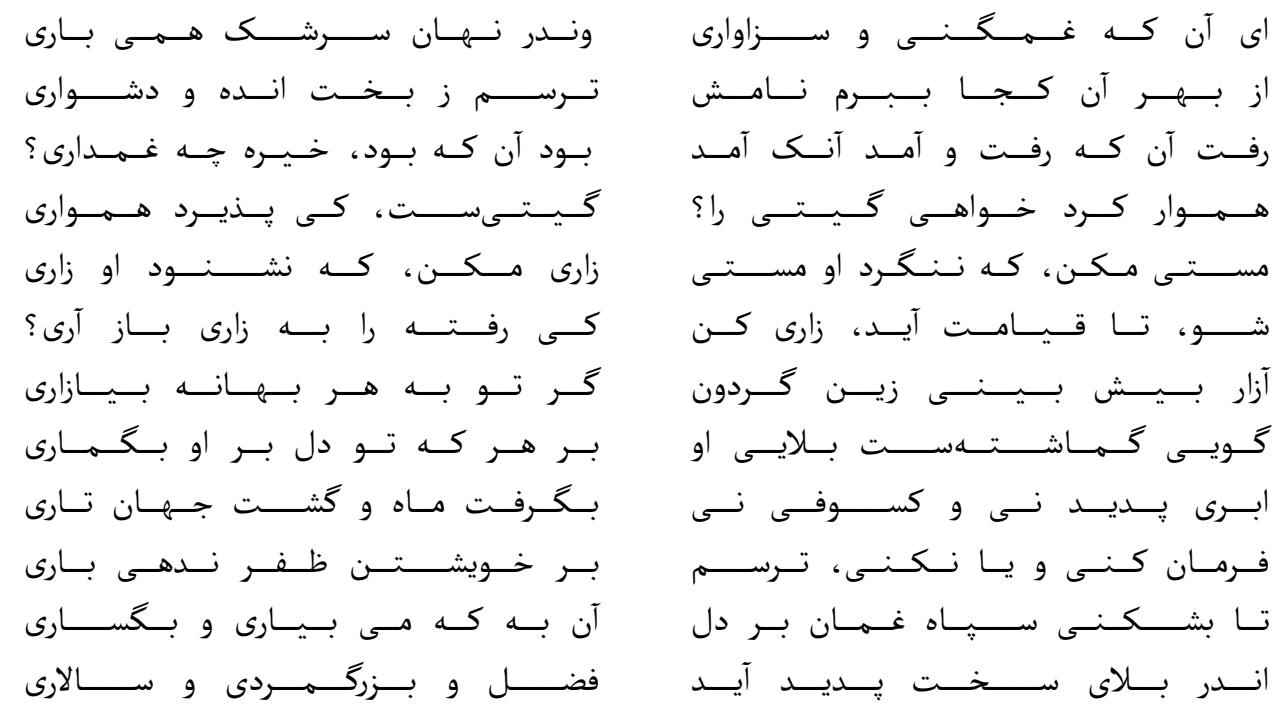

1. Ey kederli ve bu gama layık ve münasip olan kimse! Gizlice gözyaşı döküyorsun,

2. Eğer adını zikretsem şiddetli bir sıkıntı ve elem seni saracak diye korkuyorum.

3. Gitmesi gereken kimse gitti, yapılması gereken yapıldı. Olması gereken şey oldu. Niçin beyhude kederleniyorsun?

4. Dünyayı kendine ebedi ve daimi mi yapmak istiyor musun? Dünya bu! Kim ebedi ve daimi olacak?

5. Şikâyet etme çünkü dikkate almıyor. Ağlayıp inleme çünkü duymuyor.

6. Git kıyamet kopuncaya kadar ağla. Olmuş bir olayı kim ağlayıp inleyerek eski haline döndürebilir?

7. Eğer her bahane ve sıkıntı nedeniyle incinir ve kırılırsan, bu dünyada daha fazla eziyet çekeceksin.

8. Gönül bağladığın herkesin başına muhtemelen dünya bir bela getirecek.

9. Bir bulut bile aşikâr değil, güneş tutulması meydana gelmemiş ama ay ve dünya karanlı̆ga bürünmüss.

10. İster dinle ister dinleme. Kendine mukayyet olamayacağından korkuyorum.

11. Gam ordusunu yenmen için en iyi şey, şarap getirip içmendir.

12. Kederli bir olayda üstünlük, azamet, sürur ve padişahlık belli olur. (Rûdekî-i Semerkandî, 1376:111-12) 
Rûdekî vefat eden şair Ebû'l-Hasan Murâdî için on iki beyitlik bir mersiye yazmıştır. Mûrâdî Sâmânîlerden Nasr b. Ahmed ve şair Rûdekî’nin muasırı olup Arapça ve Farsça şiirler yazmıştır. Sadece iki beyti günümüze ulaşmıştır.
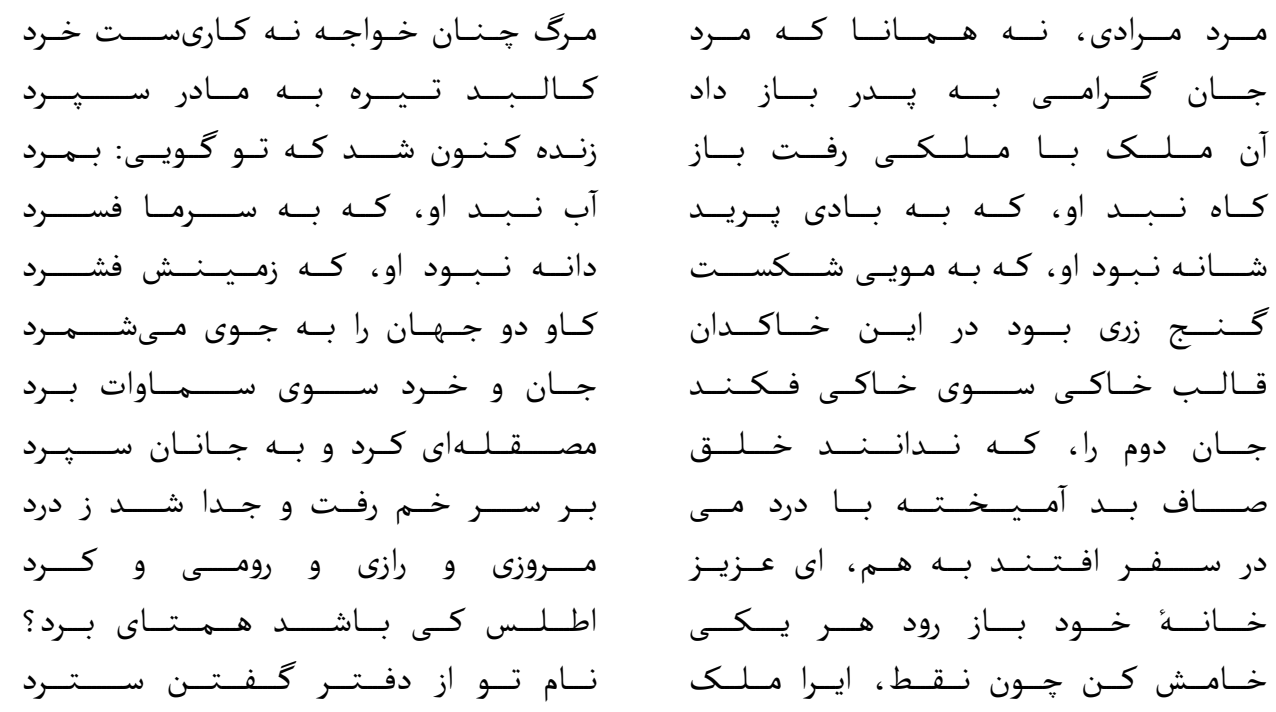

1. Murâdî öldü ama aslında tam ölmedi. Onun gibi birisinin ölümü küçük bir iş değildir.

2. Murâdî’nin ruhu gökyüzüne ulaştı. Vücudu toprağa verildi.

3. Melekler âlemiyle ruhu irtibat halindeydi ve o âleme gitti. Sen onu ölü tasavvur ediyorsun ama aslında o yaşıyor.

4. Murâdî rüzgârda uçuşan saman değildi. Soğukta donan ve buz tutan su da değildi.

5. Murâdî bir saç tanesiyle kırılan tarak değildi. Zeminin sakladığı bir dane de değildi.

6. Murâdî bu dünyada altından bir hazineydi. Her iki dünya onun için değersiz ve önemsizdi.

7. Murâdî topraktan yaratılan vücudunu, dünyanın toprak renkli âlemine attı. Ruh ve düşüncesini semaya götürdü.

8. Murâdî insanların tanımadı̆̆ı ruhu cilalayıp nurlandırdı ve Allah’a teslim etti.

9. Onun ruhu tortuya karışan şarap gibiydi. Ruhu dünya küpünden göğe yükselip toprak olan vücuttan ayrıldı.

10. Her seyahate farklı şehir, ülke ve çeşitli taifelerden insanlar birbiriyle birlikte olur.

11. Seyahatten döndüklerinde herkes kendi evine gider. Ancak ipek kumaşı nasıl kıymetli Yemen kumaşıyla aynı fiyatta olabilir?

12. Ey Rudeki sus! Kendi haline bak, çünkü en kısa zamanda Allah, senin adını da şiir ve şairlik defterinden silecek. (Rûdekî-i Semerkandî, 1376:76)

Şehîd-i Belhî Arapça ve Farsça söyleyen Sâmânî dönemi filozof ve şairlerindendir. Üstatlıkta Rûdekî̀ye denk sayılan Şehîd Fars edebiyatında ilk defa mülemma yazan şairdir. Menûçihrî-i Dâmgânî, Rûdekî, Ferruhî-i Sistânî, Fesâ̂̂, Dakîkî, Hâkânî, Edîb Sâbir ve Sûzenî gibi ünlü şairler kendisine övgüde bulunmuşlardır. Günümüzde tezkire, sözlük ve cönklerden bize ulaşan rubâî, kaside, gazel, kıta ve mesnevilerinin beyit sayısı yaklaşık 102'dir. Fars edebiyatında ilk olgun rubâî yazan şairlerden biridir. H.325 yıllında vefat etmiş ve şair Rûdekî onun ölümü üzerine altı beyitlik bir mersiye yazmıştır. (Safâ, 1338:389-393)

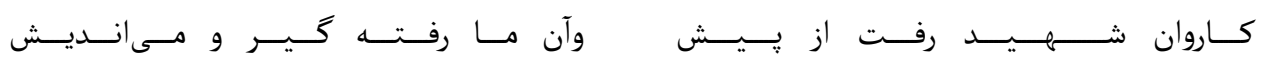


Bibliometric evaluation based on Scopus Database: The studies carried out on Mevlana Jalaluddin Rumi / İ. Şeref; B. Karagöz (p. 253-262)
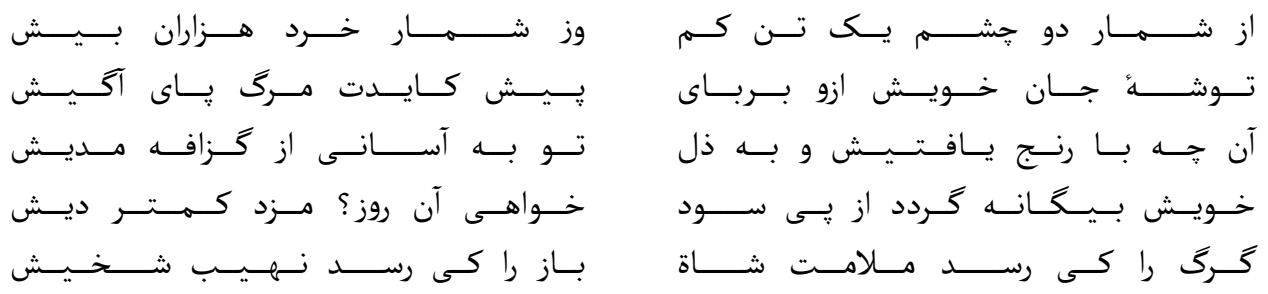

1-Şehid Belhi’nin cenazesini uğurlayan grup önümüzden geçti. Ancak sen onu ölmüş tasavvur etme, ruh ve canımızı ölmüş tasavvur et.

2-Zahiren sayıca bir kişi azaldı. Ancak bilgelik ve zekâ bakımında sanki binlerce bilgili ve zeki kimse vefat etti.

3-Ölüm ayağına dolanıp seni bulmadan önce can azığını ve hayat yiyeceğini ölüm pençesinde kurtar.

4-Sıkıntı ve zorlukla elde ettiğin şeyi rahat ve beyhude bir şekilde kaybetme.

5 -Hısım ve akrabaların para nedeniyle yabancılar gibi senden yüz çevirdiğini günü görmek istiyorsan, onlara az para ver.

6-Kurt asla aslan gibi sağlam ve kuvvetli olamaz. Serçenin korku ve telaşı asla doğana erişemez. (Rûdekî-i Semerkandî, 1376:94)

‘Ammâre-i Mervezî: Asıl adı Ebû Mansûr 'Ammâre b. Muhammed Mervezî'dir. Kendisi Sâmânîlerin sonu ile Gaznelilerin başında yaşayan şairlerdendir. Güzel ve ilgi çekici şiirler yazan 'Ammâre'nin şiirleri Enverî zamanında örnek alınmıştır. Şiirlerinde Gazneli Mahmûd'a övgüde bulunmuş ve h.395 yıllında vefat etmiştir. Yüz küsur beyti günümüze ulaşmıştır. Sâmânîlerin, el-Muntasır lakabıyla şöhret bulan son şehzade Ebû İbrâhîm İsmâil b. Nûh b. Mansûrûn h.395 ylllında öldürülmesi üzerine bir mersiye söylemiştir: (Hidâyet, 1339:888; Avfî, 1361:24; Safâ, 1338:452)

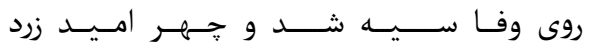

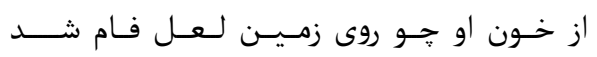

$$
\begin{aligned}
& \text { مرك از نهـيـب خويش مر آن شــاه را بخـورد }
\end{aligned}
$$

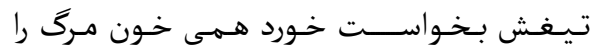

Onun kanıyla yeryüzü yakut gibi olunca, vefanın yüzü karardı ve ümidin çehresi sarardı.

Onun oku ölümün kanını içmek istiyordu ama ölüm kendi korkusundan o şahı öldürdü.

Rebîncenî: Asıl adı Ebû'l-Abbâs Fazl b. Abbâs Rebencenî’dir. Sâmânî dönemi şairlerindendir. Hicri dördüncü asırda yaşamıştır. Doksan küsur beyti günümüze ulaşmıştır. Ferruhî ve Menûçihrî gibi şairler kendisini methetmişlerdir. H.331 yllında vefat eden Nasr b. Ahmed’in ölümü ve Nuh b. Nasr'ın tahta çıkışı için yazdığı mersiye, taziye ve tebrik tarzındaki kasidesi meşhurdur çünkü bu şiir mersiye ve kutlamayı bir arada işleyen ilk Farsça eserlerdendir: (Avfî, 1361:9-10; Safâ, 1338:395-96, Hidâyet, 1339:945-46)
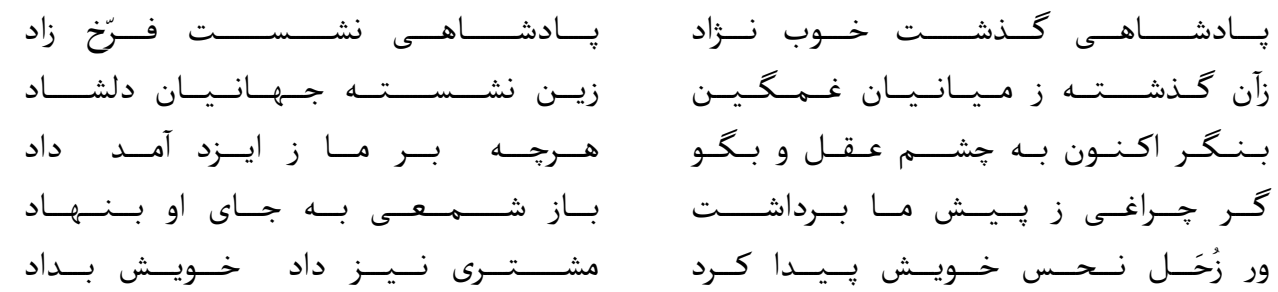

Soylu bir padişah öldü, uğurlu bir padişah onun yerine geçti.

Ölen padişah nedeniyle herkes kederli, yerine geçen padişahtan dolayı herkes mutlu.

Şimdi akıl gözüyle bak ve söyle Allah’tan bize ne geldiyse aynı adalettir.

Eğer bizim önümüzden bir lamba aldıysa da onun yerine tekrar bir mum koydu. 
Satürn uğursuzluğuyla gelmesine rağmen Jüpiter de adaletiyle geldi.

\section{Sonuç}

Fars edebiyatındaki mersiyeleri resmî, şahsî-ailevî ve dinî olarak gruplandırmak mümkündür. Ayrıca sel, veba ve deprem gibi afetler nedeniyle yazllan mersiyeler de bulunmaktadır. Hükümdarlar, vezirler ve devletin ileri gelenleri için yazılan resmî mersiyelerde resmî atmosferin gereği olarak şairler yapmacık bir tavır takınmıştır. Şahsî-ailevî mersiyelerde şairler gerçek duygularını ifade etmişlerdir. Dinî mersiyelerdeyse şairler şahsî-ailevî mersiyelerdeki kadar etkileyici olmasalar da yürek acılarını dinî duygularla ifade etmişlerdir. Fars edebiyatında mersiye türünde kendisinden şiir nakledilen ilk şair Rûdekî’dir. Rûdekî'den önceki şairlerin divanları günümüze ulaşmadığından mersiye söyleyip söylemediklerini bilmiyoruz. Rûdekî'den sonra mersiye yazan Ebû'l-Abbâs Fazl b. Abbâs Rebincenî ve Ebû Mansûr Ammâre-i Mervezî gibi şairlerin sınırlı sayıdaki beyitleri günümüze ulaşmıştır. Fars edebiyatında günümüze ulaşan ilk mersiyeleri Sâmânî dönemi şairleri yazmışlardır. Sâmânî şairleri mersiyelerinde dünya ve makamın geçiciliğini, feleğin acımasızlığını ve ölümden kurtuluşun mümkün olmadığını vurgulanmışlardır. Fars edebiyatındaki büyük şairlerin neredeyse tamamı mersiye yazmıştır. İlk mersiyelerde mübalağa ve yapmacıklık azdır. Şairler sözlerini sarih ve açık bir şekilde ifade etmişlerdir.

\section{Kaynakça}

Asîl, H. (1381). "Mersiye" Ferhengnâme-i Edeb-i Fârsî, Nşr. Hasan Enûşe, Tahran.

Avfî, M. (1361). Tezkire-i Lübâbü'l-Elbâb, Nşr. Edward Browne, C.2, Tahran.

Devletşâh, A. B. (1337). Tezkiretu'ş-şu'arâ, Nşr. Muhammed Abbâsî, Tahran.

Dihhudâ, A. E. (1377). "Mersiye” Lügâtnâme-i Dihhuda, C.13, (s.20617), Tahran.

Ferruhî-i Sîstânî, (1335). Dîvân-i Eş'âr-i Ferruhî-i Sîstânî, nşr. Debîr Seyâkî, İkbâl: Tahran.

Fesâ̂i, M. R: (1373). Envâ-i Şi rr-i Fârsî, Şîrâz.

Firdevsî, Şâhnâme-i Firdevsî, Nşr. Dervîş Perverde, Çâphâne-i Berûhîm.

Hâfiz-i Şîrâzî, (1341). Dîvân-i Hâfiz, Nşr. Hâşim Rizâ, İntişârât-i Kâve.

Hânlerî, Z. (1347). Ferheng-i Edebiyât-i Fârsî, Tahran.

Hidâyet, R. K. (1339). Mecmu'u'l-fusahâ, Nşr. Mezâher Musafâ, C.2, Tahran.

Kâzî, N. (1373). "Murûrî Ber Mersiye ve Mersiye Perdâzî Der Edebiyât-i Fârsî,” Rûznâme-i Âferîniş, Se Şenbe, 28 Tîrmâh, Tahran.

Muhammedî, H. (1387). “Kohenterîn Mersiye Serâî Der Şi'r-i Pârsî,” Keyhân Ferhengî, Tahran.

Muhteşem-i Kâşânî, (1348). Dîvân-i Eş‘âr-i Muhteşem-i Kâşânî, Nşr. Mihr Ali Gorgânî, Mahmudî.

Nefîsî, S. (1336). Muhît-i Zindegî ve Ahvâl ve Eş'âr-i Rûdekî, Tahran.

Öztürk, M. (2008). "Rûdekî" DİA, C.35. (s.185-86), İstanbul: Türkiye Diyanet Vakfı.

Provençal, E. L. (1987). "Mersiye” İslam Ansiklopedisi, C.7, (s.772-73), İstanbul.

Rûdekî-i Semerkandî, (1376). Dîvân-i Rûdekî-i Semerkandî, Nşr. Saîd-i Nefîsî, Müessese-i Enteşârât-i Nigâh, Tahran.

Safâ, Z. (1338). Târîh-i Edebiyyât Der Îrân, C.1, Tahran.

Secâdî, Z. (1373). Mersiye Serâî Der Edeb-i Fârsî, Keyhân Hevâî, Çehârşenbe, Yekom-i Tîrmâh, (s.4362), Tahran.

Selçuk, E. (2013). “İran Edebiyatında Mersiye Türleri,” Doğu Araştırmaları, (s.5-22), İstanbul. 
262 / RumeliDE Journal of Language and Literature Studies 2019.15 (June)

Bibliometric evaluation based on Scopus Database: The studies carried out on Mevlana Jalaluddin Rumi / İ. Şeref; B. Karagöz (p. 253-262)

Şâfiî, H. (1380). Sad Şâ ir, Tahran.

Şânzerî, A. R. (1394). Sebk-i Mersiyehâ-i Hâkânî, Fünûn-i Edebî, (s.139-156), Tahran.

Şemîsâ, S. (1385). Envấ-i Edebî, Mîtrâ, Tahran.

Türk Dili ve Ansiklopedisi, (1986). "Mersiye" C.6, (s.272-73), İstanbul: Dergâh.

Vezînpûr, N. (1374). Dâ̆ğ-i Neneg Ber Sîmâ-i Edeb-i Fârsî, Muîn, Tahran.

Yazıcı, T. (2004). "Mersiye" DİA, C.29, (s. 217-18), İstanbul: Türkiye Diyanet Vakfı. 